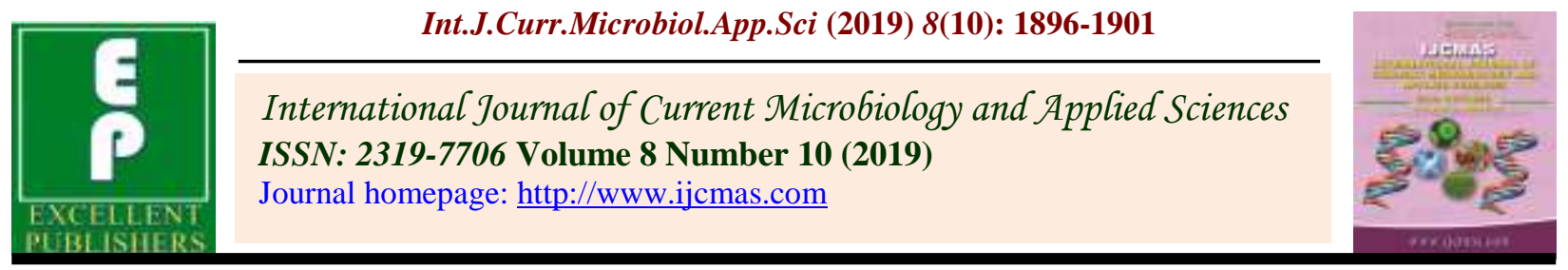

Original Research Article

https://doi.org/10.20546/ijcmas.2019.810.220

\title{
Influence of Seed Priming with Chemicals, Micronutrients and Bio-Inoculants on Growth and Yield Attributes in Foxtail Millet (Setaria italica L.)
}

\author{
S.H. Gangadharayya ${ }^{1 *}$, S.M. Prashant ${ }^{2}$, N.M. Shakuntala ${ }^{1}$, K. Vijay Kumar ${ }^{1}$, \\ L.N. Yogeesh ${ }^{2}$ and D. Krishnamurthy ${ }^{2}$
}

${ }^{1}$ Department of Seed Science and Technology, ${ }^{2}$ Agriculture Research Station, Hagari College of Agriculture, University of Agricultural Sciences, Raichur- 584 104, India

*Corresponding author

\begin{tabular}{|c|}
\hline Keywords \\
\hline $\begin{array}{l}\text { Priming, Days to } \\
\text { maturity, Seed } \\
\text { yield, Fodder yield }\end{array}$ \\
\hline Article Info \\
\hline $\begin{array}{l}\text { Accepted: } \\
\text { 15 September } 2019 \\
\text { Available Online: } \\
10 \text { October } 2019\end{array}$ \\
\hline
\end{tabular}

\section{A B S T R A C T}

Foxtail millet is an important nutri cereals which sustains well in adverse conditions like limited rainfall, poor soil fertility. It has capacity to withstand drought, adaptable to poor environment and input management. A field experiment was conducted at agriculture Research Station, Hagari during Kharif 2018-19 to know the influence of seed priming with chemicals, micro nutrients and bio-inoculants on growth and seed yield in Foxtail millet. In the present study the twelve priming treatments were used. Among the treatments, $\mathrm{T}_{12}$ (Seed priming with Azospirillum (20\%) + Pseudomonas fluorescens $(20$ $\%)+$ Phosphobacter $(20 \%)+\mathrm{Zn} \mathrm{SO}_{4}(0.1 \%)+$ Boron $(0.1 \%)$ recorded significantly highest plant height and number of tillers at 30,60 DAS and at harvest $(52.25 \mathrm{~cm}, 133.70$ $\mathrm{cm}$ and $134.12 \mathrm{~cm}$ respectively and 5.18, 5.37 and 5.37 tillers per plant respectively). Days to 50 per cent flowering and days to maturity was lower (52 and 92 days respectively). In addition to this, significantly highest panicle length $(27.58 \mathrm{~cm})$, panicle weight $(42.87 \mathrm{~g})$, seed yield per plant $(16.28 \mathrm{~g})$, seed yield per hectare $\left(2720 \mathrm{~kg} \mathrm{ha}^{-1}\right)$, fodder yield per hectare $\left(8196 \mathrm{~kg} \mathrm{ha}^{-1}\right)$ and test weight $(3.66 \mathrm{~g})$ were observed for $\mathrm{T}_{12}$ (Seed priming with Azospirillum $(20 \%)+$ Pseudomonas fluorescens $(20 \%)+$ Phosphobacter $(20 \%)+\mathrm{Zn}$ $\mathrm{SO}_{4}(0.1 \%)+$ Boron $(0.1 \%)$ compared to control $\left(21.90 \mathrm{~cm}, 26.83 \mathrm{~g}, 9.23 \mathrm{~g}, 1480 \mathrm{~kg} \mathrm{ha}^{-1}\right.$, $4681 \mathrm{~kg} \mathrm{ha}^{-1}$ and $2.80 \mathrm{~g}$ respectively).

\section{Introduction}

Foxtail millet is commonly known as Italian millet, German millet, Siberian millet, and foxtail bristle grass. Foxtail millet grows 2-5 feet tall and can be cultivated in drier and cooler regions when compared with other millets. It is currently grown in China, India, Europe, particularly in Portugal, Turkey, Hungary, France and Spain, in Asia, primarily in Korea, Pakistan, Myanmar, Bhutan, Nepal, and South Africa. It is used for feeding birds and as livestock feed in the developed countries and for food in some parts of Asia. It 
is suitable for inclusion in multiple or intercropping systems because of its short duration nature.

Seed enhancement is a term used in industry and in scientific literature to describe beneficial techniques performed on seeds, after harvesting but prior to sowing for improving a crop's harvested yield and quantity. Rapid germination and emergence is an important determinant of successful plant establishment (Heydecker et al., 1975) and seed priming has presented promising results, for many crop seeds (Bradford, 1986).

Seed priming is a controlled hydration process that involves exposing seeds to low water potentials that restrict germination (radicle protrusion), but permits pre germinative physiological and biochemical changes to occur (Heydecker and Coolbear, 1977; Bradford, 1986; Khan, 1992). Upon rehydration, primed seeds may exhibit faster rate of germination, more uniform emergence, greater tolerance to environmental stresses, and reduced dormancy in many species (Khan, 1992). The present investigation was carried out to know the different seed priming effect on growth and grain yield of foxtail millet.

\section{Materials and Methods}

The experiment was carried out at Agricultural Research Station, Hagari, Ballari during kharif season 2018. Under the present investigation twelve treatments were taken to study their effect on the crop growth and quality of foxtail millet. The experiment was laid out in randomized block design (RBD) comprising twelve treatment combinations viz. Control $\left(\mathrm{T}_{1}\right)$, Hydro priming $\left(\mathrm{T}_{2}\right)$, Seed priming with $\mathrm{KH}_{2} \mathrm{PO}_{4}(2 \%)\left(\mathrm{T}_{3}\right)$, Halo priming with $\mathrm{NaCl}$ (2\%) $\left(\mathrm{T}_{4}\right)$, Seed priming with Azospirillum sp. @ 20\% $\left(\mathrm{T}_{5}\right)$, Seed priming with P. fluorescens @ 20\% ( $\left.\mathrm{T}_{6}\right), \quad$ Seed priming with Phosphobacter @ 20\% ( $\left.\mathrm{T}_{7}\right)$, Seed priming with Azospirillum sp. @ 20\%+P. fluorescens @ 20\% + Phosphobacter@20\% ( $\left.\mathrm{T}_{8}\right)$, Seed priming with $\mathrm{ZnSO}_{4}(0.1 \%) \quad\left(\mathrm{T}_{9}\right)$, seed priming with Boron $(0.1 \%) \quad\left(\mathrm{T}_{10}\right)$, Seed priming with $\mathrm{ZnSO}_{4}(0.1 \%)+$ Boron $(0.1 \%)$ $\left(\mathrm{T}_{11}\right), \mathrm{T}_{8}+\mathrm{T}_{11}\left(\mathrm{~T}_{12}\right)$. Seeds of foxtail millet cv.HN - 46 were soaked with chemicals and bio inoculants with seed to solution ratio $(\mathrm{w} / \mathrm{v})$ of 1:1 under ambient conditions for 8 hours. Each treatment was replicated thrice.

\section{Results and Discussion}

Foxtail millet seeds primed with $\mathrm{T}_{12}$ (Seed priming with Azospirillum sp. @ 20\% + Pseudomonas fluorescens @ 20\%+ Phosphobacter @ 20\%+ $\mathrm{ZnSO}_{4} 0.1 \%$ + Boron $0.1 \%)$ recorded highest plant height $(52.25 \mathrm{~cm}$, $133.70 \mathrm{~cm}$ and $134.12 \mathrm{~cm}$ ), number of tillers (5.18, 5.37 and 5.37 respectively)at 30,60 DAS and at harvest respectively. Days to $50 \%$ flowering and days to maturity recorded lower number of days (52 and 92 days respectively) in $\mathrm{T}_{12}$. While, control $\left(\mathrm{T}_{1}\right)$ recorded lowest plant height $(35.70 \mathrm{~cm}, 109.30 \mathrm{~cm}$ and $116.80 \mathrm{~cm})$ and number of tillers $(3.54,3.85$ and 3.8) at 30,60DAS and at harvest respectively. Days to 50\% flowering and days to maturity recorded highest number of days (55 and 96 DAS respectively) in control $\left(\mathrm{T}_{1}\right)$ (Table 1).

Improvement in growth parameters might be due to combined effect of bio fertilizers and micronutrients. The enhanced plant height may also be due to the improved and faster plant emergence in bio-primed seeds which might have created nitrogen fixation by the plant, phosphorous solubilization and also cooperative competition among the plants for light and resulted in taller plants. In addition increased the nutrient availability, Azospirillum and PSB also effects the plant growth through production of growth harmone like IAA, $\mathrm{GA}_{3}$, Cytokinin (Sattar and Gaur, 1987). 
Table.1 Influence of seed priming with chemicals, micronutrients and bio inoculants on, days to 50\%flowering, days to maturity, plant height and number of tillers in foxtail millet

\begin{tabular}{|c|c|c|c|c|c|c|c|c|}
\hline \multirow[b]{2}{*}{ Treatments } & \multirow{2}{*}{$\begin{array}{l}\text { Days to } \\
50 \% \\
\text { flowering }\end{array}$} & \multirow{2}{*}{$\begin{array}{l}\text { Days to } \\
\text { maturity }\end{array}$} & \multicolumn{3}{|c|}{ Plant height(Cm) } & \multicolumn{3}{|c|}{ Number of tillers } \\
\hline & & & $\begin{array}{c}\text { 30 } \\
\text { DAS }\end{array}$ & $\begin{array}{c}\text { 60 } \\
\text { DAS }\end{array}$ & $\begin{array}{c}\text { At } \\
\text { harvest }\end{array}$ & $\begin{array}{c}\text { 30 } \\
\text { DAS }\end{array}$ & $\begin{array}{c}60 \\
\text { DAS }\end{array}$ & $\begin{array}{c}\text { At } \\
\text { harvest }\end{array}$ \\
\hline$T_{1}:$ Control & 55 & 96 & 35.70 & 109.30 & 116.80 & 3.54 & 3.85 & 3.85 \\
\hline $\mathrm{T}_{2}:$ Hydro priming & 55 & 96 & 39.90 & 113.80 & 119.00 & 3.73 & 4.02 & 4.02 \\
\hline $\mathrm{T}_{3}:$ Seed priming with $\mathrm{KH}_{2} \mathrm{PO}_{4}(2 \%)$ & 54 & 95 & 40.60 & 119.80 & 124.20 & 4.02 & 4.26 & 4.26 \\
\hline $\mathrm{T}_{4}:$ Halo priming with $\mathrm{NaCl}(2 \%)$ & 54 & 95 & 40.33 & 114.67 & 119.00 & 3.90 & 4.22 & 4.22 \\
\hline $\mathrm{T}_{5}$ : Seed priming with Azospirillum sp. @20\% & 53 & 95 & 44.13 & 125.00 & 125.93 & 4.23 & 4.38 & 4.38 \\
\hline $\begin{array}{l}\mathbf{T}_{6}: \text { Seed priming with Pseudomonas fluorescens } \\
\text { @ } 20 \%\end{array}$ & 54 & 95 & 44.07 & 123.33 & 125.20 & 4.17 & 4.36 & 4.36 \\
\hline T $:$ Seed priming with Phosphobacter @ 20\% & 54 & 95 & 43.40 & 120.73 & 124.30 & 4.07 & 4.29 & 4.29 \\
\hline $\begin{array}{l}\mathrm{T}_{8} \text { : Seed priming with Azospirillum sp. @ 20\% } \\
\text { Pseudomonas fluorescens @ 20\%+Phosphobacter } \\
20 \%\end{array}$ & 53 & 93 & 49.00 & 129.80 & 131.00 & 5.10 & 5.15 & 5.15 \\
\hline $\mathrm{T}_{9}:$ Seed priming with $\mathrm{ZnSO}_{4}(0.1 \%)$ & 53 & 94 & 46.37 & 126.83 & 130.53 & 4.97 & 5.05 & 5.05 \\
\hline$T_{10}$ : Seed priming with Boron $0.1 \%$ ) & 53 & 94 & 46.33 & 125.67 & 126.13 & 4.43 & 4.44 & 4.44 \\
\hline $\begin{array}{l}\mathrm{T}_{11}: \text { Seed priming with } \mathrm{ZnSO}_{4}(0.1 \%)+\text { Boron } \\
0.1 \%)\end{array}$ & 53 & 94 & 46.67 & 128.80 & 130.00 & 5.00 & 5.07 & 5.07 \\
\hline$T_{12}: T 8+T 11$ & 52 & 92 & 52.25 & 133.70 & 134.12 & 5.18 & 5.37 & 5.37 \\
\hline Mean & 53.63 & 94.75 & 44.06 & 122.61 & 125.51 & 4.36 & 4.18 & 4.18 \\
\hline S. Em \pm & 0.69 & 0.711 & 1.94 & 2.39 & 1.70 & 0.11 & 0.11 & 0.11 \\
\hline C.D at $5 \%$ & NS & NS & 5.70 & 7.01 & 5.0 & 0.32 & 0.33 & 0.33 \\
\hline
\end{tabular}


Table.2 Influence of seed priming with chemicals and bio inoculants on panicle length, panicle weight, test weight seed yield per plant, seed yield per hectare and fodder yield per hectare in foxtail millet

\begin{tabular}{|c|c|c|c|c|c|}
\hline Treatments & $\begin{array}{l}\text { Panicle } \\
\text { length } \\
\text { (cm) }\end{array}$ & $\begin{array}{c}\text { Panicle } \\
\text { weight }(g)\end{array}$ & $\begin{array}{l}\text { Test } \\
\text { Weight } \\
\text { (g ) }\end{array}$ & $\begin{array}{l}\text { Seed yield } \\
\text { /ha }(\mathbf{k g})\end{array}$ & $\begin{array}{l}\text { Fodder } \\
\text { yield/ha } \\
\quad(\mathbf{k g})\end{array}$ \\
\hline$T_{1}:$ Control & 21.90 & 26.83 & 2.80 & 1480 & 4681 \\
\hline$T_{2}:$ Hydro priming & 22.33 & 31.58 & 2.84 & 1610 & 5357 \\
\hline $\mathrm{T}_{3}:$ Seed priming with $\mathrm{KH}_{2} \mathrm{PO}_{4}(2 \%)$ & 22.58 & 33.40 & 3.08 & 2032 & 6482 \\
\hline $\mathrm{T}_{4}$ : Halo priming with $\mathrm{NaCl}(2 \%)$ & 22.57 & 31.87 & 3.01 & 1963 & 6335 \\
\hline $\mathrm{T}_{5}:$ Seed priming with Azospirillum sp. @20\% & 23.52 & 37.19 & 3.16 & 2183 & 7160 \\
\hline $\begin{array}{l}T_{6}: \text { Seed priming with Pseudomonas fluorescens } \\
@ 20 \%\end{array}$ & 23.83 & 35.45 & 3.11 & 2241 & 7123 \\
\hline $\mathrm{T}_{7}:$ Seed priming with Phosphobacter @ 20\% & 23.58 & 34.20 & 3.09 & 2187 & 6973 \\
\hline $\begin{array}{l}\mathrm{T}_{8}: \text { Seed priming with Azospirillum sp. @ } 20 \% \\
+ \text { Pseudomonas fluorescens @ } 20 \%+\text { Phosphobacter } \\
20 \%\end{array}$ & 25.17 & 41.63 & 3.30 & 2596 & 7955 \\
\hline $\mathrm{T}_{9}$ : Seed priming with $\mathrm{ZnSO}_{4}(0.1 \%)$ & 24.05 & 38.90 & 3.27 & 2195 & 7259 \\
\hline$T_{10}:$ Seed priming with Boron $0.1 \%$ ) & 24.00 & 38.52 & 3.21 & 2215 & 7218 \\
\hline $\begin{array}{l}\mathrm{T}_{11} \text { : Seed priming with } \mathrm{ZnSO}_{4}(0.1 \%)+\text { Boron } \\
0.1 \%)\end{array}$ & 24.43 & 40.08 & 3.29 & 2267 & 7275 \\
\hline$T_{12}: T 8+T 11$ & 27.58 & 42.87 & 3.66 & 2720 & 8196 \\
\hline Mean & 23.79 & 36.04 & 3.15 & 2140.83 & 6834.55 \\
\hline S. Em \pm & 0.91 & 0.89 & 0.091 & 93.08 & 265.04 \\
\hline C.D at $5 \%$ & 2.68 & 2.61 & 0.36 & 273.00 & 777.34 \\
\hline
\end{tabular}


Janardan Yadav et al., (2010) in chickpea concluded that the increase in plant height might be due to the early emergence of the bioprimed seeds which makes the plant to compete well with the weeds and higher rate of accumulation of dry matter due to atmospheric nitrogen fixation and phosphorous solubilization.

Raj et al., (2004) and Abdullahi et al., (2014) reported significant difference for number of tillers per plant in pearl millet, Gangwar and Sinha (2014) in rice. Increased leaf production due to seed bio-priming might be due to Pseudomonas fluorescence which contains physiologically active substances viz., growth regulators and nutrients that promote profuse number of tillers per plant as noticed by Sharifi et al., (2011) in maize.

Seed yield and yield attributing parameters differed significantly due to seed priming with chemicals and bio inoculants. Foxtail millet seeds primed with $\mathrm{T}_{12}$ (Seed priming with Azospirillum sp. @20\% + Pseudomonas fluorescens@20\%+Phosphobacter@20\%+ $\mathrm{ZnSO}_{4} 0.1 \%+$ Boron 0.1\%) recorded highest panicle length $(27.58 \mathrm{~cm})$, panicle weight $(42.87 \mathrm{~g})$, test weight $(3.66 \mathrm{~g})$, seed yield per hectare $(2720 \mathrm{~kg})$ and fodder yield per hectare $(8196 \mathrm{~kg})$.While the lowest recorded in control $\left(\mathrm{T}_{1}\right)(21.9 \mathrm{~cm}, 26.83 \mathrm{~g}, 2.80 \mathrm{~g}, 9.23 \mathrm{~g}, 1880 \mathrm{~kg}$, $4681 \mathrm{~kg}$ ) (Table 2).

Significant difference is found for all the yield parameters due to seed priming treatment. The increase in the panicle length may be due to the synthesis of amino acid and chlorophyll and better carbohydrates transformation which resulted in better growth and length of panicle which ultimately produced more number of seed per panicle resulting in increasing panicle weight there by increasing the yield. Similar results were also reported by Niranjan raj et al., (2004) in finger millet and Prasad et al., (2009) in wheat. Increase in yield was also contributed by $\mathrm{Zn}$ which attributed to the enhanced synthesis of carbohydrates and their transport to the site of grain production crop (Pedda-Babu et al., 2007). Similar results were also reported by various researchers due to Zinc seed priming on seed yield of wheat (Nazir et al., 2000; Harris et al., 2005; Aboutalebian et al., 2012).

The influence of bio-inoculants on the grain yield might be through their effect on actively growing regions in such a way that they encourage nitrogen fixation, phosphorous solubilization and mobilize the nutrients absorbed elsewhere towards the shoot resulting in better vegetative growth and subsequently increased yield as noticed by Nezarat and Gholami (2009) in maize. Azospirillum sp. and phosphobacter have improved photosynthesis by increasing water and nutrients absorption leading to produce more assimilate and improves translocation of metabolites from sources to sink which in turn increased the test weight in seeds (Mirzaei et al., 2010).

It may be concluded that seed priming with Azospirillum sp. @20\% + Pseudomonas fluorescens @20\% + Phosphobacter @ $20 \%+\mathrm{ZnSO}_{4} @ 0.1 \%$ + Boron @0.1\% was found to be the better treatment for growth and yield attributes in foxtail millet.

\section{References}

Abdullahi, R., Sheriff, H. H. and Buba, A., 2014, Effect of bio-fertilizer and organic manure on growth and nutrients content of pearl millet. J. Agric. Biol. Sci., 9(10): 351- 355 .

Aboutalebian, M. A., Ekbatani, G. Z. and Sepehri, A., 2012, Effects of on-farm seed priming with zinc sulfate and urea solutions on emergence properties, yield and yield components of three rainfed wheat cultivars. Annals of Bio. Res., 3(10): 4790-4796.

Bradford, K. J., 1986, Manipulation of seed water relations via osmotic priming to prove germination under stress condition. Hort. Sci., 21: 1105-1112.

Chhibba, I. M., Nayyar, V. K. and Kanwa, J. S., 2007, Influence of mode and source of applied iron on fenugreek (Trigonella 
corniculata) in a typic ustochrept in Punjab, India. Int. J. Agric. and Biol., 9:254 -256.

Gangwar, G. P. and Sinha, A. P., 2014, Effect of fungal and bacterial bio-agent application on total phenolic content in rice leaves pre-inoculated with Xanthomonas oryzae pv. Oryzae (Uyeda and Ishiyama) Dowson. J. App. Natural Sci., 6(1): 254:257.

Harris, D., Breese, W. A., Kumar Rao, J. V. D. K., 2005, The improvement of crop yield in marginal environments using 'on-farm' seed priming: nodulation, nitrogen fixation and disease resistance. Australian J. Agric. Res., 56:1211-1218.

Heydecker, W. and Coolbear, P., 1977, Seed treatments for improved performance. Survey and attempted prognosis. Seed Sci. and Technol., 5(3): 353-425.

Heydecker, W., Higgins, J. and Urner, Y. J., 1975, Invigoration of seeds. Seed Sci. and Technol., 3: 881-888.

Janardan Yadav., Jay Prakash Verma and Kavindra Nath Tiwari., 2010, Effect of plant growth promoting Rhizobacteria on seed germination and plant growth Chickpea (Cicer arietinum L.) under in vitro conditions. Int. J. Biol. Forum., 2(2): $15-18$.

Khan, A. A., 1992, Preplant physiological seed conditioning. Hort. Rev., 14: 131-181.

Meena, R, P., Sendhil, R., Tripathi, S. C., Chander, S., Chhokar, R. S. and Sharma, R. K., 2013, Hydro-priming of seed improves the water use efficiency, grain yield and net economic returns of wheat under different moisture regimes. $J$. Agric., 11:149-159.

Mirzaei, A., Vazan, S., Naseri, R., 2010, Response of yield components of safflower (Carthamus tinctorius L.) to seed incolution with Azotobacter and Azosprilium and different nitrogen levels under dry land condition. World. Appl. Sci. J., 11(10): 1287- 1291.

Nazir, M. S., Jabbar, A., Mahmood, K., Ghaffar, A. and Nawaz, S., 2000, Morphochemical traits of wheat as influenced by pre sowing seed steeping in solution of different micronutrients. Int. J. Agric. and Biol., 2:6-9.

Nezarat, S. and Gholami, A., 2009, Screening plant growth promoting Rhizobacteria for improving seed germination, seedling growth and yield of maize. Pak. J. Bio. Sci., 12(1): 26-32.

Pedda-Babu, P., Shanti M., Prasad B. R. and Minhas, P. S., 2007, Effect of zinc on rice in rice - black gram cropping system in saline soils. The Andhra Agric. J., 54:4750.

Prasad, B., Prasad, R., Singh, A. and Prasad, S., 2009, Presowing seed inoculation of wheat (Triticum aestivum L. cv. VL 832) for seed yield and quality enhancement in North West Himalayan agriculture system. J. Crop and Weed. 5(2): 80-86.

Raj, N. S., Shetty, N. P. and Shetty, H. S., 2004, Seed biopriming with Pseudomonas fluorescens isolates enhances growth of pearl millet plants and induces resistance against downy mildew. Int. J. Pest Mgt. 50(1): 41- 48 .

Sattar, M. A. and Gaur, A. C., 1987, Production of auxins and gibberellins by phosphate dissolving microorganisms. Zentral. Microbiol., 142: 393-395.

Sharifi, R. S., Khavazi, K. and Gholipouri, A., 2011, Effect of seed priming with plant growth promoting Rhizobacteria (PGPR) on dry matter accumulation and yield of maize (Zea mays L.) hybrids. Int. Res. J. Biochem. Bioinf., 1:76-83.

\section{How to cite this article:}

Gangadharayya, S.H., S.M. Prashant, N.M. Shakuntala, K. Vijay Kumar, L.N. Yogeesh and Krishnamurthy, D. 2019. Influence of Seed Priming with Chemicals, Micronutrients and BioInoculants on Growth and Yield Attributes in Foxtail Millet (Setaria italica L.). Int.J.Curr.Microbiol.App.Sci. 8(10): 1896-1901. doi: https://doi.org/10.20546/ijcmas.2019.810.220 